\title{
Quality of Life - Exemplified through Patients Living with Atrial Fibrillation
}

Vibeke Høgh $^{1 \star}$, Charlotte Delmar ${ }^{2}$, Sam Riahi $^{3}$ and Kirsten Frederiksen ${ }^{4}$

${ }^{1}$ Aalborg Atrial Fibrillation Study Group, Department of Cardiology, Aalborg University Hospital, Denmark

${ }^{2}$ Professor, Section of Nursing, Institute of Public Health, Faculty of Health Sciences, Aarhus University, Denmark

${ }^{3}$ Department of Cardiology, Aalborg University Hospital, Denmark

${ }^{4}$ Associate Professor, Section of Nursing, Institute of Public Health, Faculty of Health Sciences, Aarhus University, Denmark

"Corresponding author: Vibeke Høgh, Aalborg Atrial Fibrillation Study Group, Department of Cardiology, Aalborg University Hospital, Science and Innovation Centre, Soendre skovvej 15, Room number 505, DK-9000 Aalborg, Denmark, Tel: +45 23743586; Fax: +45 99326813; E-mail: vih@rn.dk

Received date: July 28th, 2013, Accepted date: April 2nd, 2014, Published date: April 12th, 2014

Copyright: (c) 2014 Høgh V, et al. This is an open-access article distributed under the terms of the Creative Commons Attribution License, which permits unrestricted use, distribution, and reproduction in any medium, provided the original author and source are credited.

\section{Abstract}

Background: Health-related quality of life is a frequently assessed patient-reported outcome in the current literature on patients living with atrial fibrillation. Originally, quality of life is an abstract, complex concept, and there is no consensus on a final definition of it. Considering overall quality of life to be assessable using a standardised tool may lead to the loss of valuable knowledge about the patients' individual lived experiences.

Aim: To report how the concept of quality of life is being defined and which arguments are given for using the concept in scientific research papers on patients living with atrial fibrillation.

Method: Systematic literature study based on analysis of 53 scientific research papers on patients living with atrial fibrillation and inspired by Leif Becker Jensen's suggestions on how to perform text analysis on a hermeneutical process described by Hans Georg Gadamar.

Findings: Three ways of defining the concept of quality of life and five preferred ways of giving reasons for using the concept were found. Thirteen of the papers offered no definition of the concept of quality of life, while 19 papers did not offer arguments for using the concept.

Conclusion: Quality of life is seen reduced into assessable parameters like health status. This might lead to the loss of valuable insight into the patients' subjective perception of their lives. To avoid this reduction in future, it is important to call for clear definitions and arguments for assessing quality of life, and to confront a suggested implicit societal agreement within scientific research.

Keywords: Atrial fibrillation; Literature study; Patient-reported outcome; Patients' subjective outcome; Qualitative method; Quality of life

\section{Introduction}

Atrial fibrillation (AF) is the most common cardiac arrhythmia, affecting approximately $1-2 \%$ of the general population, and more than 6 million Europeans suffer from this arrythmia [1]. The prevalence of $\mathrm{AF}$ is progressing and is expected to at least double within the next fifty years [1].

In a review paper on patient-reported outcomes, Coyne et al. state [2] that health-related quality of life (QOL), together with symptoms due to $\mathrm{AF}$, is the most frequently assessed patient-reported outcome in the current literature on patients living with AF. In a systematic review, Thrall et al. [3] point out that patients living with AF are likely to report a significantly poorer health-related QOL score than healthy controls and patients with coronary heart diseases. According to Engelmann and Godtfredsen [4], the influence on QOL is often captured by using assessable evaluation tools, both generic and disease-specific.
The concepts of QOL and health-related QOL have been widely discussed in the international literature in general for patients suffering from chronic diseases [5-7]. However, this discussion is not new. According to Gill and Feinstein [8], the basis for measuring QOL within the medical literature seems to struggle with the desire to measure things that cannot be measured. Regarding patients living with AF, Jenkins and Bubien also elaborate on issues and difficulties in the usage of the concept of QOL [9]. A clear definition of the concept of QOL is missing, and according to Moons et al. [10] this can lead to confusion in understanding the concept. Bergland and Narum [11] report existence of more than 100 different definitions of QOL. However, they conclude that by nature QOL is versatile and abstract. They therefore suggest defining QOL as an 'umbrella concept' [11]. Moons et al. illuminate [10] six problems related to working with the concept of QOL, as follows; 1.QOL vs. health status and functioning; 2. Objective vs. subjective dimensions; 3 . Distinction between indicators and determinants; 4. Changes over time; 5 . Negative vs. positive components; 6. Health-related QOL. Moons et al. [10], emphasise that the most appropriate way of defining QOL is by the phrase 'satisfaction with life'. Additionally, according to Kahneman it should be discussed how we can distinguish between general life satisfaction and the patients' subjective assessment of their current physical and emotional state [12]. QOL is defined by the World Health 
Organisation (WHO) as; “..individuals' perception of their position in life in the context of the culture and value systems in which they live and in relation to their goals, expectations, standards and concerns" [13].

In accordance with this definition, Zachariae et al. state that QOL is multidimensional and consists of objective and subjective aspects, and is rated from the individual's point of view [14]. Historically, there has been a desire to define QOL as an assessable patient-reported outcome since the World War II (WWII), defining QOL in a materialistic manner to improve living conditions [15]. This is inconsistent with the original content of the concept of QOL, leading back to Aristotle (344-322 BC) who described it as 'happiness', and later on, it appears as a socioeconomic concept as 'the greatest happiness principle' described by Bentham (1748-1832) [11]. As a socioeconomic concept, the desire was to involve peoples' perceptions in ethical discussions in the society. In the 1970s, researchers worked on elucidating the original meaning of QOL as a subjective and dynamic concept [11]. In the 1990s, the focus of concern in QOL research was a definition of the concept [11]. Thus, as indicated by Zachariae and Bech [14], there might be a possible sign of a historical duality between a biomedical desire to assess health-related QOL as a patient-reported outcome, and a humanistic desire to focus on the patients' subjective lived experience and perceptions in regard to the overall QOL. Hamming and Vries [16] explain that QOL contains more subjective elements than health status, which is a patient self-reported evaluation thus emphasising the importance of distinguishing between QOL and health status. The importance of distinguishing between health and QOL is also supported by Moons et al. [10]. According to Chin and Kramer [17], the complexity of a concept requires definitions and argumentation. According to Moons et al. [10], it is crucial to discuss the concept of QOL to minimise ambiguity. In this paper, we will elaborate on the use of QOL in scientific research papers on patients living with AF to illustrate the complexity and context dependency of the concept of QOL.

We therefore suggest that the terms health-related QOL and health status only cover a part of the individual persons overall QOL, and thereby that it is important to distinguish between the terms, which has also been emphasised eralier by Guyatt et al. [18], Apers et al. [19] and Moons [20]. Related to the context of patients living with AF the prefix of 'health-related' to QOL, is often considered. We therefore suggest a potential for a conflict between the way QOL is being used in science and research today and the original understanding of the concept as a multidimentional concept capturing the individual's perception and experience of their position in life. The aim of this paper is to report how QOL has been defined and the reasons that have been given for using it in scientific research papers on patients living with $\mathrm{AF}$.

\section{Material and Method}

The specific research questions for the study were; 'How is the concept of quality of life defined?' and 'what reasons are given for using the concept of quality of life?'. We used the literature study method based on text analysis to guide our analysis on scientific research papers on patients living with AF. According to Silverman [21], it is important to describe why and how text analysis is used. In this study, we used the text analysis to examine the above mentioned expected contradictory and hidden content, applying QOL. As suggested by Koch and Vallgårda [22] text analysis can elaborate on issues of hidden and contradictory contents in texts. The analysis was carried out based on the Danish scholar Leif Becker Jensen's suggestions on how to perform text analysis [23] as a hermeneutical process described by the German philosopher Hans Georg Gadamar [24]. We started our analysis by reading all the included papers to get an overall impression. We then repeatedly read the papers keeping an open mind and trying to understand them from the perspective of the author. In our analysis, we considered major limitations of space, and requirements by editors and readers to stick to the point when one is describing research whose measured outcome is health-related QOL in scientific papers. We followed the three levels of text analysis suggested by Becker Jensen [23]. The text close analysis level enabled us to identify the content, the communicative level aimed to recognise where and why the text was written, and finally the societal level, which allowed us to elucidate the influence of societal factors [23]. To make it possible to report the result of our analysis, we used a schedule with the following issues; Author, publication year, purpose, design, context/country, definition of QOL, reasons for using QOL and findings.

\section{Search strategy}

The literature search, following Stoltz et al. [25], and Polit and Becks' [26] recommendations for literature search was performed on 4 February 2013. We wanted to identify research papers on patients living with $\mathrm{AF}$, where the concept of QOL was included. Of 502 possible hits, 53 texts were included in the study [2-4,27-75]. Details on the systematic literature search in Cinahl, PubMed, The Danish National Library Database and the Cochrane Library are demonstrated in Figure 1. 

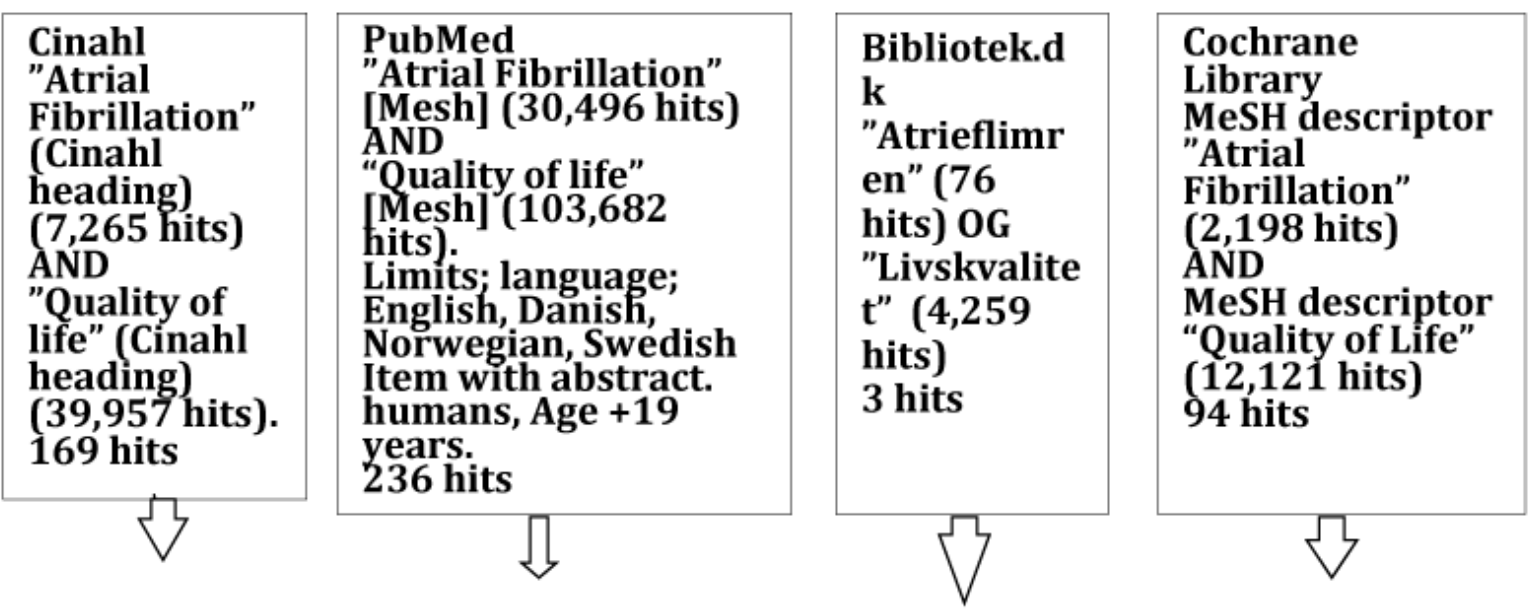

\section{2 hits}

Figure 1: Presentation of the systematic literature search strategy, performed on 4 February 2013.

The process of inclusion and exclusion was performed by reading titles and abstracts of the total number of hits. Inclusion criteria were; patients with AF, the concept of QOL was included in the text, and the text was a scientific research paper. Exclusion criteria were; treatmentspecific texts, patients with pacemakers, editorial comments and children (under 18 years). A librarian from the Danish National Library of Health Sciences was consulted during the systematic literature search.

\section{Results}

\section{The text close analysis level}

The findings are presented in Table 1, and the structure of this analysis is reported in Figure 2.

As shown in Figure 2, a clear definition of the concept of QOL was lacking in 13 of the 53 selected papers, even though the concept was used as the outcome of the study described in the paper. In relation to this, abbreviations like QOL, HRQOL (health-related QOL) and HS (health status) were used without defining or differentiating between them in eight of the papers $[46,49,55-57,60,66,74]$. In 29 of the papers,
QOL or health-related QOL was defined as an evaluating and assessable parameter. For example, Valderrama et al. [68] referred to other studies using Short Form-36 (SF-36) as a research outcome. In eight of these studies, we found argument for measuring QOL or health-related QOL, referring to SF-36 as the most valid and widely applied tool $[27,35,46,53,54,61,75,76]$. In six of the papers $[4,28,33,36,46,57]$, QOL or health-related QOL was defined as a multidimensional concept with subjective elements which was hard to assess and use as outcome in clinical trials. Furthermore, these papers also emphasised the importance and difficulties in working with the concept. Five of the papers used the WHO definition $[3,31,32,38,60]$, and multidimensional aspects were also included in their arguments. The paper written by McCabe et al. [73] examplified the importance of including qualitative descriptive perspectives as well, when working with the concept of QOL. Five of the papers called for a new tool for integration in clinical practice and clinical trials $[51,55,57,62,74]$. The limitations of assessing the patient's subjective perspective using a generic tool were emphasised. In six of the papers without definition of QOL, arguments for use of the concept of QOL were also missing $[39,40,43,48,65,67]$. 
Citation: Høgh V, Delmar C, Riahi S, Frederiksen K (2014) Quality of Life - Exemplified through Patients Living with Atrial Fibrillation. J Nurs

\begin{tabular}{|c|c|c|c|c|}
\hline Author & $\begin{array}{l}\text { Pub. } \\
\text { Year }\end{array}$ & Design & Definition of quality of life & $\begin{array}{l}\text { Arguments for using the concept of quality } \\
\text { of life }\end{array}$ \\
\hline Kang and Bahler [31] & 2004 & Cross sectional study & $\begin{array}{l}\text { Health-related quality of life defined by the World } \\
\text { Health Organisation. (W) }\end{array}$ & $\begin{array}{l}\text { Focus on the concept as multidimensional and } \\
\text { subjective. } \\
\text { Critical regarding use of the concept in other } \\
\text { studies and the random use of abbreviations } \\
\text { and labels for the concept. Critical regarding the } \\
\text { use of the concept as an effect outcome in } \\
\text { studies. Emphasises the importance of the } \\
\text { individual perception of the concept and } \\
\text { involving physiological aspects of the concept. } \\
\text { (M) }\end{array}$ \\
\hline Kang[32] & 2006 & Cross sectional study & $\begin{array}{l}\text { Health-related quality of life defined by the World } \\
\text { Health Organisation. (W) }\end{array}$ & $\begin{array}{l}\text { Critical regarding the use of health-related } \\
\text { quality of life as an effect goal. Argues that } \\
\text { health-related quality of life is important to use } \\
\text { and investigate even though it is hard to work } \\
\text { with. (M) }\end{array}$ \\
\hline Maryniak et al. [38] & 2006 & Questionnaire study & $\begin{array}{l}\text { Cites the World Health Organisation's definition of } \\
\text { quality of life -"individuals' perception of their } \\
\text { position in life in the context of the culture and } \\
\text { value systems, in which they live and in relation to } \\
\text { their goals, expectations and standards". (W) }\end{array}$ & $\begin{array}{l}\text { Emphasises the importance of humans' } \\
\text { subjective evaluation of quality of life. Uses a } \\
\text { symptom checklist together with the SF-36 } \\
\text { questionnaire. (M) }\end{array}$ \\
\hline Thrall et al. [3] & 2006 & $\begin{array}{l}\text { Systematic literature } \\
\text { study }\end{array}$ & $\begin{array}{l}\text { "Patient-related issue" } \\
\text { Refers to the historical evolution of the concept } \\
\text { going back to the 1940's where the World Health } \\
\text { Organisation extended the definition of health to } \\
\text { "encompass the presence of physical, mental and } \\
\text { social well-being". Quality of life has been more } \\
\text { and more important as an outcome in research } \\
\text { since 1980's. (W) }\end{array}$ & $\begin{array}{l}\text { Emphasises quality of life as an important } \\
\text { parameter instead of just focusing on mortality } \\
\text { and morbidity related to different treatment } \\
\text { strategies. Assessments of quality of life have } \\
\text { been used in many settings e.g. to screen for } \\
\text { psychological morbidity, to prioritise patients for } \\
\text { various treatment, to determine the choice of } \\
\text { treatment, to monitor patients' progress, and as } \\
\text { an outcome measure in clinical trials. Relates to } \\
\text { methodology weaknesses in the use of the } \\
\text { concept (small sample size, no control group, } \\
\text { short term follow-up periods and non-validated } \\
\text { tools to assess quality of life). Emphasises the } \\
\text { need for studies focusing on atrial fibrillation and } \\
\text { its influence on people in a more general way. } \\
\text { Quality of life is particularly relevant to treatment } \\
\text { of chronic conditions. (M) }\end{array}$ \\
\hline Paquette et al. [27] & 2000 & $\begin{array}{l}\text { Double-blinded } \\
\text { randomised multicenter } \\
\text { study }\end{array}$ & $\begin{array}{l}\text { Quality of life assessed as a parameter. Short } \\
\text { Form } 36 \text { and Toronto Atrial Fibrillation Severity } \\
\text { scale. Duke activity status index, Symptom } \\
\text { Checklist. (P) }\end{array}$ & $\begin{array}{l}\text { Short Form } 36 \text { is used because it is the most } \\
\text { valid tool. }(\mathrm{T})\end{array}$ \\
\hline $\begin{array}{l}\text { Engelmann } \\
\text { Pehrson [29] }\end{array}$ & 2004 & Literature study & $\begin{array}{l}\text { Health-related quality of life as an effect } \\
\text { parameter. }(P)\end{array}$ & $\begin{array}{l}\text { Emphasises problems of using quality of life as } \\
\text { an effect goal. Health-related quality of life can } \\
\text { be affected by many different factors and is } \\
\text { multidimensional by nature. (M) }\end{array}$ \\
\hline $\begin{array}{l}\text { Suzuki and } \\
\text { Kasanuki [30] }\end{array}$ & 2004 & Questionnaire study & $\begin{array}{l}\text { Quality of life can be assessed as a parameter. } \\
\text { Quality of life is assessed by Scale of Disease } \\
\text { and quality of life. }(P)\end{array}$ & $\begin{array}{l}\text { Arguments related to the importance of } \\
\text { psychosocial aspects in the multidimensional } \\
\text { concept quality of life instead of just focusing on } \\
\text { somatic aspects as seen in earlier studies. (M) }\end{array}$ \\
\hline Van den Berg et al. [35] & 2001 & Questionnaire study & Measuring quality of life from Short Form 36. (P) & $\begin{array}{l}\text { Justifies the use of Short Form } 36 \text { as a } \\
\text { standardised and valid generic questionnaire. } \\
\text { Gives a short description of the elements of the } \\
\text { questionnaire but does not further justify the } \\
\text { selection of tool. (T) }\end{array}$ \\
\hline $\begin{array}{l}\text { Lünderitz and Jung } \\
{[36]}\end{array}$ & 2000 & Literature study & $\begin{array}{l}\text { Defines the concept as a multidimensional } \\
\text { construction. Highlights a consensus regarding } \\
\text { "quality of life is measurable on basis of four } \\
\text { parameters". (M) }\end{array}$ & $\begin{array}{l}\text { States that working with quality of life is } \\
\text { important, and that this work can be } \\
\text { complicated. Validity in earlier studies is lacking. } \\
\text { (M) }\end{array}$ \\
\hline Hegbom et al. [75] & 2006 & Intervention study & $\begin{array}{l}\text { Defines health-related quality of life and uses the } \\
\text { Short Form } 36 \text { questionnaire as measurement. } \\
\text { (P) }\end{array}$ & $\begin{array}{l}\text { Refers to other studies where Short Form } 36 \\
\text { has been used. Uses Short Form } 36 \text { because it } \\
\text { is a valid generic tool. ( } T \text { ) }\end{array}$ \\
\hline
\end{tabular}


Citation: Høgh V, Delmar C, Riahi S, Frederiksen K (2014) Quality of Life - Exemplified through Patients Living with Atrial Fibrillation. J Nurs

\begin{tabular}{|c|c|c|c|c|}
\hline Badia et al. [37] & 2007 & $\begin{array}{l}\text { Literature study and } \\
\text { validation of a disease- } \\
\text { specific questionnaire }\end{array}$ & $\begin{array}{l}\text { Defines health-related quality of life as it can be } \\
\text { assessed from a parameter. }(P)\end{array}$ & $\begin{array}{l}\text { Emphasises that working with development of a } \\
\text { disease specific tool can reduce the individuality } \\
\text { in the patients' perceptions, and points out that } \\
\text { it is important to involve patients in the process. } \\
\text { (M) }\end{array}$ \\
\hline Lane and Lip [28] & 2009 & Literature study & $\begin{array}{l}\text { Mentions that quality of life is a multidimensional } \\
\text { construction but also that it is assessable using } \\
\text { different scales. (M) }\end{array}$ & $\begin{array}{l}\text { Emphasises methodology weaknesses in } \\
\text { studies concerning quality of life. Emphasises } \\
\text { that quality of life is being misused in the } \\
\text { meaning of health. States that patients' } \\
\text { perspective on the concept is an important } \\
\text { outcome which can give important information in } \\
\text { clinical trials. (M) }\end{array}$ \\
\hline $\begin{array}{l}\text { Reynolds, Ellis and } \\
\text { Zimetbaum [33] }\end{array}$ & 2008 & Literature study & $\begin{array}{l}\text { A subjective phenomena based on humans' } \\
\text { individual perception and created through } \\
\text { experiences, believes and expectations. (M) }\end{array}$ & $\begin{array}{l}\text { Emphasises multidimensional aspects regarding } \\
\text { the phenomena and discusses the roles of } \\
\text { these aspects included when working with the } \\
\text { concept. Critical regarding usage of quality of } \\
\text { life as a measurement in the body of a } \\
\text { standardised questionnaire and as an effect } \\
\text { goal for a treatment. (M) }\end{array}$ \\
\hline $\begin{array}{ll}\text { Engelmann } & \text { and } \\
\text { Godtfredsen [4] }\end{array}$ & 2004 & Literature study & Multidimensional concept. (M) & $\begin{array}{l}\text { Emphasises the importance of working with the } \\
\text { concept, but also that the concept is subjective } \\
\text { and therefore can be difficult to work with. (M) }\end{array}$ \\
\hline Siaplaouras et al. [39] & 2005 & Effect study & $\begin{array}{l}\text { No definition of the concept. Uses a questionnaire } \\
\text { with a scale } 1-5 .(N)\end{array}$ & $\begin{array}{l}\text { No arguments for using the concept quality of } \\
\text { life as an effect parameter. }(\mathrm{N})\end{array}$ \\
\hline Härden et al. & 2009 & $\begin{array}{l}\text { Validation of a disease- } \\
\text { specific questionnaire }\end{array}$ & $\begin{array}{l}\text { No definition. Uses health-related quality of life. } \\
\text { (N) }\end{array}$ & $\begin{array}{l}\text { No further reasoning for using the concept than } \\
\text { the concept is important to take into account in } \\
\text { clinical practise. }(\mathrm{N})\end{array}$ \\
\hline Dorian et al. [34] & 2009 & $\begin{array}{l}\text { Validation of a scale to } \\
\text { assess rubjective } \\
\text { assessment of quality of } \\
\text { life }\end{array}$ & No definition of the concept. $(\mathrm{N})$ & $\begin{array}{l}\text { Important to use the concept of quality of life in } \\
\text { clinical practise to reach understanding of the } \\
\text { patients' subjective and specific perception of } \\
\text { their situation. (I) }\end{array}$ \\
\hline Ong. et al. [41] & 2006 & Questionnaire study & $\begin{array}{l}\text { No definition of the concept. No differentiation } \\
\text { between health-related and non-health-related } \\
\text { quality of life. The two concepts are assimilated. } \\
\text { (N) }\end{array}$ & $\begin{array}{l}\text { Refers to results from other studies related to } \\
\text { impaired quality of life among patients suffering } \\
\text { from atrial fibrillation. Assimilates health status } \\
\text { and quality of life. Splits up quality of life into } \\
\text { mental and physical parts, referring to Short } \\
\text { Form 36. Emphasises the importance of } \\
\text { focusing on human factors with influence on } \\
\text { quality of life instead of only focusing on } \\
\text { disease-related factors. (M) }\end{array}$ \\
\hline Sears et al. [43] & 2005 & Questionnaire study & $\begin{array}{l}\text { No definition of the concept. Assimilates health- } \\
\text { related quality of life with general quality of life. } \\
\text { (N) }\end{array}$ & $\begin{array}{l}\text { No arguments for working with the concept } \\
\text { except for reference to other studies where the } \\
\text { concept has been included. }(N)\end{array}$ \\
\hline Dagres et al. [65] & 2007 & Cohort study & $\begin{array}{l}\text { No definition of the concept. Quality of life is } \\
\text { measured by EQ-5D and EQ-VAS. (N) }\end{array}$ & $\begin{array}{l}\text { Usage of the two scales is not discussed, and } \\
\text { no reasons are given }(\mathrm{N})\end{array}$ \\
\hline Funk et al. [66] & 2007 & Literature review & $\begin{array}{l}\text { No definition of the concept. Health-related quality } \\
\text { of life is used as an effect outcome. Health- } \\
\text { related quality of life and quality of life are used } \\
\text { randomly. }(\mathrm{N})\end{array}$ & $\begin{array}{l}\text { Emphasises that quality of life is an } \\
\text { important "outcome" for assessing the effect of } \\
\text { an intervention. Criticises the huge occurrence } \\
\text { of tools which makes it difficult to compare study } \\
\text { outcomes. Emphasises the desire to increase } \\
\text { the stringency in working with assessing health- } \\
\text { related quality of life. (I) }\end{array}$ \\
\hline Dorian et al. [72] & 2000 & Questionnaire study & $\begin{array}{l}\text { No definition. Mentions health-related quality of } \\
\text { life but uses the abbreviation "QOL". Mentions } \\
\text { global quality of life which is subjective and can } \\
\text { be expected to be affected by chronic diseases. } \\
\text { (N) }\end{array}$ & $\begin{array}{l}\text { Elucidates that different tools are used for } \\
\text { measuring patients' quality of life. Emphasises } \\
\text { problems related to the non-existence of a } \\
\text { specific questionnaire which can assess } \\
\text { subjective aspects of quality of life and mentions } \\
\text { that it might be a problem to measure these } \\
\text { aspects. (I) }\end{array}$ \\
\hline Thrall et al. [67] & 2007 & Questionnaire study & No definition of the concept. $(\mathrm{N})$ & $\begin{array}{l}\text { Emphasises methodology weaknesses in earlier } \\
\text { quality of life studies. Gives no reasons for } \\
\text { using the concept. (N) }\end{array}$ \\
\hline
\end{tabular}


Citation: Høgh V, Delmar C, Riahi S, Frederiksen K (2014) Quality of Life - Exemplified through Patients Living with Atrial Fibrillation. J Nurs

\begin{tabular}{|c|c|c|c|c|}
\hline Pontoppidan et al. [69] & 2009 & Prospective study & Measuring quality of life from Short Form 36. (P) & $\begin{array}{l}\text { No arguments for using Short Form } 36 \text { are } \\
\text { giving. }(\mathrm{N})\end{array}$ \\
\hline Kang [70] & 2009 & $\begin{array}{l}\text { Descriptive comparative } \\
\text { study }\end{array}$ & Quality of life measured from Short Form 36. (P) & $\begin{array}{l}\text { Describes the concept in details, but gives no } \\
\text { reasons for using it. }(N)\end{array}$ \\
\hline Lane et al. [28] & 2009 & Questionnaire study & $\begin{array}{l}\text { Measuring health-related quality of life from Short } \\
\text { Form } 36 .(P)\end{array}$ & No reasons for using the concept are given. $(\mathrm{N})$ \\
\hline Ong et al. [41] & 2006 & Cross sectional study & $\begin{array}{l}\text { Measuring quality of life by Short Form } 36 \text {. Uses } \\
\text { health-related quality of life and quality of life } \\
\text { randomly. Assimilates the two concepts but only } \\
\text { defines health- related quality of life. }(P)\end{array}$ & No further arguments for using the concept. (N) \\
\hline $\begin{array}{l}\text { Valderrama, Dunbar } \\
\text { and Mensah [68] }\end{array}$ & 2005 & Literature study & Refers to other studies, using Short Form 36. (P) & No arguments for using the concept. $(\mathrm{N})$ \\
\hline $\begin{array}{l}\text { Palm Johansen et al. } \\
\text { [44] }\end{array}$ & 2012 & Literature review & $\begin{array}{l}\text { No definition of the concept. } \\
\text { Uses the Danish term "Livskvalitet" - "quality of } \\
\text { life". Refers to studies where the concept has } \\
\text { been used. }(N)\end{array}$ & $\begin{array}{l}\text { Describes quality of life as an important } \\
\text { measurement when wanting to obtain } \\
\text { knowledge on patients' perceptions of living with } \\
\text { atrial fibrillation. (I) }\end{array}$ \\
\hline Bohnen et al. [45] & 2011 & Questionnaire study & $\begin{array}{l}\text { Quality of life assessed by four scales: } \\
\text { Physical condition, Psychological wellbeing, } \\
\text { Social activities and Everyday activity. } \\
\text { Quality of life is described as a parameter. A } \\
\text { specific questionnaire designed to include both } \\
\text { patients and their spouses has been developed. } \\
\text { (P) }\end{array}$ & $\begin{array}{l}\text { No direct argument for assessing quality of life. } \\
\text { Refers to other studies where quality of life has } \\
\text { been used as an assessable effect parameter } \\
\text { (N) }\end{array}$ \\
\hline Reynolds et al. [74] & 2010 & $\begin{array}{l}\text { Randomised controlled } \\
\text { trial }\end{array}$ & $\begin{array}{l}\text { Uses the abbreviation QOL. Describes that } \\
\text { quality of life can be assessed as an effect } \\
\text { parameter. Uses Short Form } 36 \text { and Symptom } \\
\text { Severity Checklist. }(P)\end{array}$ & $\begin{array}{l}\text { Refers to other studies where quality of life has } \\
\text { been seen as an assessable effect parameter. } \\
\text { Short Form } 36 \text { is used because it is an } \\
\text { extensively validated generic measure. Short } \\
\text { Form } 36 \text { has been used in many other studies } \\
\text { regarding patients living with atrial fibrillation. (T) }\end{array}$ \\
\hline $\begin{array}{l}\text { Perret- Guillaume et al. } \\
\text { [46] }\end{array}$ & 2010 & Cross sectional study & $\begin{array}{l}\text { Using the concepts of health status and health- } \\
\text { related quality of life. Defines quality of life as a } \\
\text { multidimensional concept, based on the patients' } \\
\text { perception. Differs between quality of life and } \\
\text { health-related quality of life. Uses two } \\
\text { instruments; MOS -SF- } 36 \text { and Duke Health } \\
\text { profile. (M) }\end{array}$ & $\begin{array}{l}\text { Uses generic measures to be able to compare } \\
\text { the participants, without regard to a specific } \\
\text { disease. } \\
\text { Emphasises that the selected instruments have } \\
\text { been validated and used by others. }(T)\end{array}$ \\
\hline McCabe et al. [73] & 2011 & $\begin{array}{l}\text { Qualitative descriptive } \\
\text { interview study }\end{array}$ & $\begin{array}{l}\text { No direct definition of the concept of quality of life. } \\
\text { Refers to other studies, where quality of life has } \\
\text { been assessed from surveys. Emphasises that } \\
\text { qualitative studies are needed to describe } \\
\text { patients' experiences of living with atrial } \\
\text { fibrillation. Impaired physical functioning and } \\
\text { mental health in patients living with atrial } \\
\text { fibrillation have earlier been reported. The authors } \\
\text { emphasise the question "but how?". (N) }\end{array}$ & $\begin{array}{l}\text { The concept of quality of life is not used directly } \\
\text { in this study, but the importance of descriptive } \\
\text { studies to obtain knowledge of patients' } \\
\text { perception is being emphasised. (Q) }\end{array}$ \\
\hline Spertus et al. [47] & 2010 & $\begin{array}{l}\text { Development and } \\
\text { validation of a disease- } \\
\text { specific health status } \\
\text { questionnaire. } \\
\text { Prospective } \\
\text { observational literature } \\
\text { and interview study }\end{array}$ & $\begin{array}{l}\text { Health-related quality of life is assessed as health } \\
\text { status, in a questionnaire. The abbreviations used } \\
\text { are explained. No final definition of quality of life. } \\
\text { Refers to other studies which have shown } \\
\text { decrease in patients' quality of life in regard to } \\
\text { atrial fibrillation. (P) }\end{array}$ & $\begin{array}{l}\text { Health status is an important outcome to use in } \\
\text { clinical or research purposes, to get insight in } \\
\text { patients' evaluation and to improve quality of } \\
\text { treatment for atrial fibrillation. "Quantifying } \\
\text { patients' perceptions of their disease with } \\
\text { patient-reported outcomes is becoming an } \\
\text { increasingly important method for defining the } \\
\text { efficacy of new treatments and determining the } \\
\text { quality of healthcare" (I) }\end{array}$ \\
\hline Pappone et al. [48] & 2011 & $\begin{array}{l}\text { Randomised controlled } \\
\text { trial }\end{array}$ & $\begin{array}{l}\text { No final definition of quality of life. Assessing } \\
\text { quality of life from Short Form } 36 \text {. }(\mathrm{N})\end{array}$ & $\begin{array}{l}\text { Refers to other studies, which have shown that } \\
\text { quality of life can be impaired in patients with } \\
\text { atrial fibrillation. } \\
\text { (N) }\end{array}$ \\
\hline
\end{tabular}


Citation: Høgh V, Delmar C, Riahi S, Frederiksen K (2014) Quality of Life - Exemplified through Patients Living with Atrial Fibrillation. J Nurs

\begin{tabular}{|c|c|c|c|c|}
\hline $\begin{array}{l}\text { Guedon-Moreau et al. } \\
\text { [49] }\end{array}$ & 2010 & $\begin{array}{l}\text { Randomised controlled } \\
\text { trial }\end{array}$ & $\begin{array}{l}\text { Uses Short Form } 36 \text { as a health status } \\
\text { questionnaire, later on describes that quality of } \\
\text { life is measured using the two selected } \\
\text { questionnaires. (P) }\end{array}$ & $\begin{array}{l}\text { Refers to other studies where quality of life has } \\
\text { been used as measurements. (N) }\end{array}$ \\
\hline Mohanty et al.[50] & 2012 & Prospective study & $\begin{array}{l}\text { Uses quality of life as an assessable outcome } \\
\text { from Short Form } 36 \text { to evaluate the impact of } \\
\text { metabolic syndrome in patients undergoing } \\
\text { catheter ablation for atrial fibrillation. }(P)\end{array}$ & $\begin{array}{l}\text { Refers to earlier studies which have shown that } \\
\text { metabolic syndrome and atrial fibrillation, as } \\
\text { stand alone conditions, have been seen to } \\
\text { trigger physical, mental and psychological } \\
\text { problems which greatly impair quality of life. }(\mathrm{N})\end{array}$ \\
\hline Coyne et al. [2] & 2005 & Literature review & $\begin{array}{l}\text { Measuring health-related quality of life as a } \\
\text { patient-reported outcome measure. }(P)\end{array}$ & $\begin{array}{l}\text { Measuring health-related quality of life is an } \\
\text { important outcome to assess patients' } \\
\text { evaluation on how atrial fibrillation symptoms } \\
\text { and treatment impact their lives. It is very } \\
\text { important to be aware of what a questionnaire is } \\
\text { assessing e.g. a symptom questionnaire alone } \\
\text { cannot assess health-related quality of life. (I) }\end{array}$ \\
\hline Peinado et al. [51] & 2010 & $\begin{array}{l}\text { Prospective } \\
\text { observational } \\
\text { multicenter study }\end{array}$ & $\begin{array}{l}\text { Assesses health-related quality of life from a } \\
\text { disease-specific questionnaire (AF-QOL). No final } \\
\text { definition of the concept. Refers to other studies } \\
\text { where the concept of health-related quality of life } \\
\text { has been used. (P) }\end{array}$ & $\begin{array}{l}\text { Development and validation of a new disease- } \\
\text { specific questionnaire have been missing, and } \\
\text { assessment of patients' health-related quality of } \\
\text { life from generic measures has not been giving } \\
\text { clear results. }(O)\end{array}$ \\
\hline Lamori et al. [52] & 2012 & $\begin{array}{l}\text { Retrospective } \\
\text { observational study }\end{array}$ & $\begin{array}{l}\text { Health-related quality of life is assessed by Short } \\
\text { Form } 12 \text {. Describes Short Form } 36 \text { as a standard } \\
\text { measurement of quality of life. Refers to earlier } \\
\text { studies where quality of life has been seen as } \\
\text { impaired by dyspepsia. }(P)\end{array}$ & $\begin{array}{l}\text { Emphasises that quality of life has been } \\
\text { assessed in earlier studies. No direct argument } \\
\text { for using the concept. (N) }\end{array}$ \\
\hline Reynolds et al. [74] & 2010 & $\begin{array}{l}\text { Prospective } \\
\text { observational registry } \\
\text { study }\end{array}$ & $\begin{array}{l}\text { Health-related quality of life assessed by Short } \\
\text { Form } 12 \text { and Atrial Fibrillation Symptom } \\
\text { Checklist. } \\
\text { No final definition. (N) }\end{array}$ & $\begin{array}{l}\text { Refers to other studies where health-related } \\
\text { quality of life has been assessed. Emphasises } \\
\text { that health-related quality of life is important to } \\
\text { work with, and that there is a need for a disease } \\
\text { specific questionnaire. (O) }\end{array}$ \\
\hline Jaber et al. [53] & 2010 & $\begin{array}{l}\text { Quasi experimental } \\
\text { questionnaire study }\end{array}$ & $\begin{array}{l}\text { Individual perceptions of quality of life are } \\
\text { assessed by Short Form } 36 \text {. No further definition } \\
\text { of the concept. }(P)\end{array}$ & $\begin{array}{l}\text { Uses Short Form } 36 \text { to quantify individual } \\
\text { perceptions of health and wellbeing because it } \\
\text { is a previously validated and used tool. (T) }\end{array}$ \\
\hline Groenveld et al. [54] & 2011 & $\begin{array}{l}\text { Randomised controlled } \\
\text { trial }\end{array}$ & Quality of life is assessed by Short Form 36. (P) & $\begin{array}{l}\text { Short Form } 36 \text { is a validated and frequently } \\
\text { used questionnaire in arrhythmia studies. } \\
\text { Furthermore, Short Form } 36 \text { has been } \\
\text { translated into Dutch. (T) }\end{array}$ \\
\hline Gehi et al. [55] & 2012 & Prospective cohort study & $\begin{array}{l}\text { General health status and wellbeing assessed by } \\
\text { Short Form 12, by PCS and MCS component } \\
\text { scores. } \\
\text { Disease-specific questionnaire used: University of } \\
\text { Toronto Atrial Fibrillation Severity Scale (AFSS) } \\
\text { and Atrial Fibrillation Effect on QualiTy-of- Life } \\
\text { (AFEQT), Canadian Cardiovascular Society } \\
\text { Severity of Atrial Fibrillation Scale (CCS-SAF). } \\
\text { Refers to other studies where the concept of } \\
\text { quality of life has been used. (P) }\end{array}$ & $\begin{array}{l}\text { Development of a disease specific tool } \\
\text { regarding this group of patients is very } \\
\text { important. "A general quality of life scale may } \\
\text { not reflect symptoms particular to AF". (O) }\end{array}$ \\
\hline Fichtner et al. [56] & 2012 & $\begin{array}{l}\text { Prospective quasi } \\
\text { experimental study }\end{array}$ & $\begin{array}{l}\text { Assesses quality of life from seven validated and } \\
\text { tailoured questionnaires, both disease-specific (3) } \\
\text { and generic (4). } \\
\text { (P) }\end{array}$ & $\begin{array}{l}\text { Disease-specific tools are important and more } \\
\text { reliable to assess quality of life in patients living } \\
\text { with paroxysmal atrial fibrillation. (I) }\end{array}$ \\
\hline Dabrowski et al. & 2010 & $\begin{array}{l}\text { Prospective } \\
\text { experimental study }\end{array}$ & $\begin{array}{l}\text { Quality of life assessed using the Nottingham } \\
\text { Health Profile questionnaire. } \\
\text { Definition: "determinants of positive functioning } \\
\text { assess- ment (quality of life) include 1) Objective } \\
\text { factors such as health status (and the results of } \\
\text { medical tests), socioeconomic status (home, } \\
\text { work, income) and social relationships (their } \\
\text { quantity and quality) }\end{array}$ & $\begin{array}{l}\text { Indicates hope for development of a better tool } \\
\text { to evaluate patients' perceptions as an endpoint } \\
\text { in clinical trials. }(\mathrm{O})\end{array}$ \\
\hline
\end{tabular}


Citation: Høgh V, Delmar C, Riahi S, Frederiksen K (2014) Quality of Life - Exemplified through Patients Living with Atrial Fibrillation. J Nurs

\begin{tabular}{|c|c|c|c|c|}
\hline & & & $\begin{array}{l}\text { 2) Subjective factors: Physical (capacity, } \\
\text { complaints), mental (anxiety, depression, self- } \\
\text { perception) interpersonal (social support, } \\
\text { interactions with other persons) and social } \\
\text { (satisfaction from work, financial situation and } \\
\text { social position)". No reference to this definition is } \\
\text { mentioned except from referring to other studies } \\
\text { which have shown impaired quality of life in } \\
\text { patients with atrial fibrillation. (M) }\end{array}$ & \\
\hline Cha et al. [58] & 2011 & $\begin{array}{l}\text { A prospective cohort } \\
\text { study }\end{array}$ & Quality of life assessed using Short Form 36. (P) & $\begin{array}{l}\text { No arguments for using the concept. Refers to } \\
\text { other studies, which have shown impairment in } \\
\text { patients' quality of life in regard to atrial } \\
\text { fibrillation. (N) }\end{array}$ \\
\hline Ariansen et al. [59] & 2010 & Case-control study & $\begin{array}{l}\text { Uses "QOL" as designation on quality of life. } \\
\text { Mentions health-related quality of life (mixes up } \\
\text { designations'). Assesses quality of life from Short } \\
\text { Form } 36 \text { and the disease-specific questionnaire } \\
\text { Symptom Checklist, Frequency and Severity. (P) }\end{array}$ & $\begin{array}{l}\text { No arguments for using the concept. Refers to } \\
\text { other studies where it has been used. (N) }\end{array}$ \\
\hline Almeida et al. [60] & 2011 & Cross sectional study & $\begin{array}{l}\text { Defines quality of life from the definition provided } \\
\text { by the World Health Organisation in 1947. } \\
\text { "Quality of life is a wide concept involving several } \\
\text { factors affecting the life of a person, such as } \\
\text { social condition, health, economical status, } \\
\text { satisfaction and welfare." "Quality of Life is related } \\
\text { to the subjective perception, on health status and } \\
\text { on how a disease affects the persons life, } \\
\text { involving both physical, functional, emotional and } \\
\text { social aspects" } \\
\text { Describes that quality of life was evaluated from } \\
\text { two questionnaires - one generic (Short Form } 36 \text { ) } \\
\text { and one disease-specific Duke Anticoagulation } \\
\text { Satisfaction Scale. (W) }\end{array}$ & $\begin{array}{l}\text { Refers to the importance of evaluating the } \\
\text { subjective perception from the patients' } \\
\text { perspective. States that quality of life has been } \\
\text { evaluated in a few earlier studies. } \\
\text { Both selected instruments were easy to use and } \\
\text { self-explanatory. Emphasises that both } \\
\text { instruments have been validated in Brazil. (M) }\end{array}$ \\
\hline Steg et al. [62] & 2012 & $\begin{array}{l}\text { International, } \\
\text { observational, } \\
\text { sectional survey }\end{array}$ & $\begin{array}{l}\text { Quality of life assessed by the questionnaire } \\
\text { EQ5D. } \\
\text { (P) }\end{array}$ & $\begin{array}{l}\text { Refers to other studies assessing quality of life. } \\
\text { EQ5D is validated in different languages. } \\
\text { Discusses the need for at disease-specific } \\
\text { questionnaire and that the existing disease- } \\
\text { specific questionnaires, related to atrial } \\
\text { fibrillation, were not available at the time, when } \\
\text { the study was performed. (O) }\end{array}$ \\
\hline Rådholm et al. [63] & 2011 & $\begin{array}{l}\text { Population-based } \\
\text { survey study }\end{array}$ & $\begin{array}{l}\text { Assesses self-estimated health related quality of } \\
\text { life from EQ-5D index value and Vas scale. }(P)\end{array}$ & $\begin{array}{l}\text { No arguments for using the concept. Refers to } \\
\text { prior studies, which have indicated impaired } \\
\text { quality of life in patients with atrial fibrillation. (N) }\end{array}$ \\
\hline Suleiman et al. [64] & 2012 & Randomised control trial & $\begin{array}{l}\text { Quality of life assessed by Atrial Fibrillation } \\
\text { Symptom Frequency and Severity Checklist. }(P)\end{array}$ & No arguments for using the concept. (N) \\
\hline Ahmed et al. [61] & 2010 & $\begin{array}{l}\text { Randomised controlled } \\
\text { trial }\end{array}$ & $\begin{array}{l}\text { Measuring general health-related quality of life, } \\
\text { using the generic Short Form } 36 \text { and other } \\
\text { disease-specific measures. (P) }\end{array}$ & $\begin{array}{l}\text { Short Form } 36 \text { is the most widely used tool to } \\
\text { assess health-related quality of life in arrhythmia } \\
\text { studies. (T) }\end{array}$ \\
\hline
\end{tabular}

Table 1: Presentation of the 53 selected scientific research papers. 


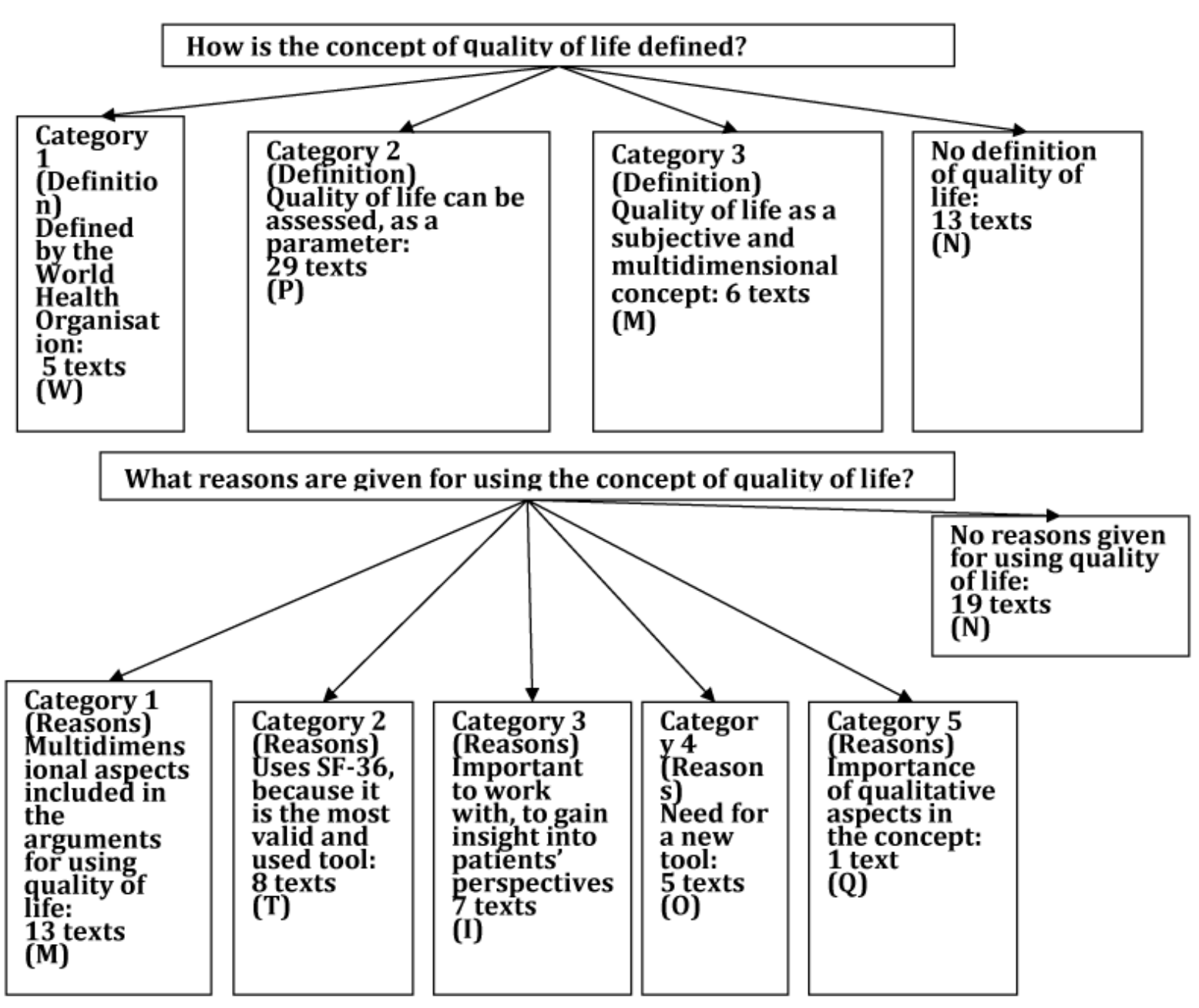

Figure 2: Structure of the results of data analysis on the definition of the concept quality of life and the reasons given for using this concept in the 53 selected scientific papers.

\section{The communicative analysis level}

Most of the papers were written by physicians with the exception of four that were written by nurses $[31,32,44,73]$. Two were written by nurses and doctors in collaboration $[45,64]$, and one paper was written by a psychologist [30]. The target population of all the papers was health care professionals. The papers were mainly questionnaire studies, literature reviews and one qualitative interview study.

\section{The societal analysis level}

The papers were published from 2000 to 2012 and were published in various countries: Japan, France, Italy, UK, US, South Korea, Israel, Canada, Spain, Poland, Norway, Sweden, Germany, the Netherlands, Brazil and Denmark.

\section{Discussion}

This section of the paper is based on three subjects which occurred during the analysis, regarding reflections on the utilisation of the concept of QOL.

\section{Sign of an implicit societal agreement}

Missing definitions and reasons for using the concept of QOL were elucidated in this study. Furthermore, it showed a "mix up" in the abbreviations that did not seem to be concise as the authors seem to fail to distinguish between QOL, health-related QOL and health status. This issue might lead to concept confusion and reduction of the original meaning of the concept, as stated by Moons et al. [10] who emphasised the crucial issue of reflecting on the use of the concept of QOL. We are aware that patients' perspective is taken into account in the design and validation of questionnaires. However, considering overall QOL equal to health-related QOL and health status may lead to risk of reducing the inidviduals lived experiences included in overall QOL as lived experiences are context dependent and situation oriented and part of the individual person's life [77].

According to Becker Jensen [23], implicit meanings of concepts may be a result of a societal agreement and thus no direct demands for a final definition are made by society when using the concept. This may be exemplified by arguments stating that SF-36 is a valid and widely applied tool $[27,35,46,53,61,74-76]$. This kind of argumentation 
might be what Becker Jensen [23] describes as 'tricks of arguments' Becker Jensen defines 'tricks of arguments' as a special type of argument characterised by being a reliable argumentation but not necessarily valid [23] (p.81). Compared to Toulmin's model of arguments (1958), 'tricks of arguments' might be regarded as the warrant in a chain of argumentation, consisting of three elements, claim, support and warrant. Lack of documentation is frequently seen within 'tricks of arguments', and justification relies on the recipient. According to Becker Jensen, 'tricks of arguments' appear in different types, for example; expert arguments, authority arguments, and genetic arguments [23] (p.81-82). Expert arguments meaning that if experts state that something is right, it is considered right and can serve as a warrant in the chain of argumentation, without demand for relevant documentation. For example in a conversation between a patient and a medical doctor, the patient believes that the doctor is right due to his education and position and does not demand further documentation. Authority arguments meaning reference to a respected authority (person or institution) can serve as a warrant for a claim, without demand for documentation of the warrant. According to Becker Jensen, one of the largest authorities in Denmark is social agreements that are likely to be implicit. In other words, the majority in a society can decide what is right. Genetic arguments meaning to conclude about the nature of something based on a description of it, for example stating: most women are stay-at-home wives, ergo women prefer to be housewives taking care of their families [23] p. 82. In this study where authors claim that SF-36 can be used as an expression of the subjective overall concept of QOL, without further definition and reflection or argument for the claim, it may be considered as what Leif Becker defines as an "expert argument" or an "authority argument" [23] (p.81-82). The use of 'tricks of arguments' might be a result of the earlier mentioned 'implicit societal agreement' stating that it is valid to consider the overall concept of QOL to be assessed using a standardised tool like SF-36.

\section{The issue of academic writing and existence of an implicit societal agreement}

With regard to academic writing where, according to Eriksson [78], Chin and Kramer [17] and Hanestad and Wahl [15], arguments and definitions play a central role for the transparency, rigour and clarity of the text, this issue of an implicit societal agreement is crucial. It underlines the importance of the author's responsibility to reflect on the concepts used.

In academic writing, a clear and transparent reasoning is commonly recommended. According to Dahlager and Fredslund [79], the reader's opportunity to gain understanding of the use of the concept is minimal, if the author does not explicate the pre-understanding including the definition and arguments for the concept used. Using the concept of QOL without explicit considerations on the concept and its connection to health status may lead to less attention on the individual's subjective lived experience. By this paper, we want to highlight the importance of arguments and definitions in scientific research.

\section{Potential consequences of not confronting an implicit societal agreement}

The findings of the societal and communicative levels of the analyses performed in the 53 selected scientific papers indicated that these results were evident in different countries and professional contexts, ranging from psychologists and doctors to nurses. It is difficult to define the contexts in which the problem of hidden societal agreement is most dominant. Moons et al. [10] point out that the discussion regarding the content of the concept of QOL (especially in the 1990s) has mostly been ongoing within humanistic research [10], which perhaps is the reason why the influence is less established within the field of biomedical research. However, Gill and Feinstein [8] comment on this issue by saying that the usage of QOL within medical literature seems to aim at the wrong target by requesting to measure something that cannot be measured. More research is required to determine relationships regarding this issue in different contexts.

In 29 of the 53 selected papers we found indication of a desire to assess QOL or health-related QOL as a measurement, a parameter. The desire to assess health-related QOL and the evaluation of measurements, disease-specific scales, generic scales, and questionnaires can be seen historically in the development of the concept. For example, Bergland and Narum write that in the post WWII period, researchers wanted to measure 'welfare' and to improve living standards [11]. It is reported in the Annals of Oncology in 1995 that for the first time the U.S. Food and Drug Administration's Guidelines approved a drug primary based on results on patientreported health outcome [80]. Additionally, it is reported by both Zacharia [81] and the user manual of the SF-36 questionnaire [82] that inclusion of patient reports on health-related QOL is requested when a new drug is being tested. This is a case of a 'silent demand' to the pharmaceutical industry, to assess health-related QOL as an 'effect goal'. A reason for assessing the patient's health-related QOL has been given by Zachariae as 'involving the patients in their own treatment'. Patients' lived experiences are by definition and explicitly taken into account in the very design, validation, and use of disease specific health-related questionnaires, and thereby a crucial foundation for the design and validation of questionnaires. Thus, trying to assess the patients' lived experiences from a standardised questionnaire may be problematic, when we consider lived experiences as context dependent and situation oriented. Hamming and Vries [16] recommend that it is important to state what is being assessed, e.g. health status, instead of denominate it all QOL. From the 53 selected papers we found that a definition of the concept of QOL was missing in 13 of the papers, and arguments for using the concept were missing in 19 of the texts. This indicates a potential for improvement and precision on what is being assessed and for what purpose in research involving the concept of QOL in the context of patients living with AF.

In their deliberations, the authors seem to fail to distinguish between QOL, health-related QOL and health status. From our point of view, this is what Moons et al. [10] state by emphasising the crucial issue of reflecting on the utility of the concept of QOL.

To articulate the implicit societal agreement within scientific research, we wish to stress the importance of reflecting on and facing these issues regarding the concept of QOL, and consequently elucidating the problems.

\section{Limitations}

Several of the selected scientific papers were based on a quantitative methodology, which is important to be aware of in understanding QOL from a hermeneutical perspective, which by nature, is qualitative. We have been attentive and open to this fact in our interpretations. QOL is complex and multidimensional and has been a popular subject in scientific research; exemplified by being included in numerous texts (see Figure 1 - 103,682 hits in the search in Pub Med on 'quality of 
life'). The aim of this study was not to clarify all aspects of the concept of QOL, but to elaborate on how QOL has been used and arguments for using it. However, specific details regarding the concept of QOL may be lost. Moreover, the aim of this study has not been to elaborate on the specific results from the selected scientific papers. This kind of study would have called for another approach e.g. a systematic review approach. Performance of this kind of study is considerable for future study plans. Additionally it may add important and valuable knowledge to the field of patient reported outcome in patients living with AF. Hermeneutical interpretation requires the researcher to be open and aware of his/her pre-understanding in order to let the text speak for itself. There is a risk of misunderstanding hidden meanings in the papers, but we have tried to be aware of this risk during the entire interpretation process, by rereading the papers several times and reminding each other and ourselves how and where the papers were written and by whom. We have tried to stay aware of the agenda and purpose of the papers. Hermeneutical interpretation is subjective and can therefore not be generalised, but according to Delmar [83] 'generalisability' in qualitative studies can be seen as 'recognition', which means a way of expressing something familiar or common. Therefore, the findings of this study cannot necessarily be transferred directly into contexts of other diseases. However, because QOL is a popular universal and widely used human concept, our findings may disclose some familiar and common things about the concept, which can be relevant to investigate in relation to other diseases. In addition, perhaps the issues related to the potential existence of an implicit societal agreement in a research field can be seen in relation to other diseases, as generic tools to assess health status such as SF-36 have also been used in other fields than patients living with AF. Therefore, there may be a potential for the existence of what is described by Becker Jensen [23] as 'implicit societal agreements' and 'tricks of arguments' in other research areas, similar to the ones found in this study.

\section{Implications for future studies}

In this study, we found that the patients' subjective lived experiences are at risk of being condensed into outcomes in standardised evaluation assessments if the concept of QOL is used unreflected without definition and argument. We find it important to elucidate this risk, to prevent reduction of the patients' subjective lived experiences in future studies. However, we also find it important to emphasise the importance of developing disease-specific questionnaires for the specific disease that the patient suffers from, as described by both Zachariae and Beck [14], Pedersen and Kupper [84] and Spertus et al. [47]. A disease-specific questionnaire must cover the specific symptoms and problems concerning the specific disease. Taking patients' experience of symptom burden into account is especially important within the population of patients living with $\mathrm{AF}$, as this is a highly heterogene group in reference to symptom burden, age and gender, as described by Camm et al. [85] as well as by McCabe [73]. However, we would suggest including qualitative as well as quantitative approaches to focus also on the patients' subjective lived experiences in future studies. The study performed by McCabe et al. [73] is an example of a qualitative approach. Most importantly, we suggest reflecting upon the concepts being used. A newly published paper by Eriksen and Risør [86] reflects upon the concept of 'symptom', which is also a central issue in future studies on the population of patients living with AF. Futhermore, Dijkers comments that a continuous discussion on QOL is needed [87].

\section{Conclusion}

Assessing the concept of QOL from a standardised assessment tool might lead to reduction of valuable insight into the patients' subjective lived experiences if left standing alone. To avoid this reduction in scientific research concerning patients living with $\mathrm{AF}$, it is important to call for a clear definition and reasoning for using the concept, and to be aware of the aspects of QOL that can be assessed using a tool and the ones that cannot. Without challenging the suggested implicit societal agreement regarding the ability of calculating patients' subjective lived experiences, the ambiguities in the use of QOL will continue.

\section{Acknowledgement}

The study was financially supported by The Danish Council for Strategic Research by being a part of one of seven $\mathrm{PhD}$ studies within the overall project "The epidemic of AF - from genes and lifestyle to disease prevention and treatment" in Aalborg AF Study Group (Reference no. 09-066965).

\section{References}

1. Camm AJ, Kirchhof P, Lip GYH, Schotten U, Savelieva I, et al. (2010) Guidelines for the management of atrial fibrillation: the Task Force for the Management of Atrial Fibrillation of the European Society of Cardiology (ESC). Eur Heart J 31: 2369-2429.

2. Coyne K, Margolis MK, Grandy S, Zimetbaum P (2005) The state of patient-reported outcomes in atrial fibrillation : a review of current measures. Pharmacoeconomics 23: 687-708.

3. Thrall G, Lane D, Carroll D, Lip GY (2006) Quality of life in patients with atrial fibrillation: a systematic review. Am J Med 119: 448.

4. Engelmann MDM, Godtfredsen J (2004) Livskvalitet hos farmakologisk behandlede atrieflimrenpatienter. [Quality of life in pharmacological treated patients living with atrial fibrillation] [Danish]. Ugeskr læger 166: 2877-2882.

5. Apers S, Luyckx K, Moons P (2013) Quality of life in adult congenital heart disease: what do we already know and what do we still need to know? Curr Cardiol Rep 15: 407.

6. Bentsen SB, Rokne B, Wahl AK (2013) Comparison of health-related quality of life between patients with chronic obstructive pulmonary disease and the general population. Scand J Caring Sci 27: 905-912.

7. Bentsen SB, Henriksen AH, Wentzel-Larsen T, Hanestad BR, Wahl AK (2008) What determines subjective health status in patients with chronic obstructive pulmonary disease: importance of symptoms in subjective health status of COPD patients. Health Qual Life Outcomes 6: 115.

8. Gill TM, Feinstein AR (1994) A critical appraisal of the quality of qualityof-life measurements. JAMA 272: 619-626.

9. Jenkins LS, Bubien RS (1996) Quality of life in patients with atrial fibrillation. Cardiol Clin 14: 597-606.

10. Moons P, Budts W, De Geest S (2006) Critique on the conceptualisation of quality of life: a review and evaluation of different conceptual approaches. Int J Nurs Stud 43: 891-901.

11. Bergland AI, Narum I (2007) Quality of Life: Diversity in Content and Meaning. Crit Rev Phys Rehabil Med 19: 115-139.

12. Kahneman D (2011) Thinking, fast and slow. New York: Farrar Straus and Giroux.

13. World Health Organization. WHOQOL Measuring Quality of Life [Internet] (1997) Div Ment Helath Prev Subst Abus.

14. Zachariae B, Bech P (2008) [Quality of life concept]. Ugeskr Laeger 170: 821-825.

15. Wahl AK, Hanestad BR. Måling av livskvalitet i klinisk praksis: en innføring [Assessing quality of life - an introduction] [Norwegian]. Oslo: Fagbokforlaget; 2004. p. 156 s. 
16. Hamming JF, De Vries J (2007) Measuring quality of life. Br J Surg 94: 923-924.

17. Chinn P, Kramer MK (2007) Udvikling af kundskaber i sygeplejen [Developing knowledge in nursing][Danish]. Kbh.: Akademisk

18. Guyatt GH1, Feeny DH, Patrick DL (1993) Measuring health-related quality of life. Ann Intern Med 118: 622-629.

19. Apers S, Luyckx K, Moons P (2013) Is quality of life the ultimate outcome parameter? Eur J Cardiovasc Nurs 12: 502-504.

20. Moons P (2004) Why call it health-related quality of life when you mean perceived health status? Eur J Cardiovasc Nurs 3: 275-277.

21. Silverman D (2006) Interpreting qualitative data: methods for analyzing talk, text and interaction. London: SAGE; p. xv, $428 \mathrm{~s}$.

22. Koch L, Vallgårda S (2007) Forskningsmetoder i folkesundhedsvidenskab [Research methods within public health research] [Danish]. Kbh.: Munksgaard Danmark. p. 301 sider, ill.

23. Becker Jensen L (2011) Indføring i tekstanalyse [Introducing text analysis] [Danish]. Frederiksberg C: Samfundslitteratur.

24. Gadamer HG (2007) Sandhed og metode: grundtræk af en filosofisk hermeneutik [Through and method - basics of philosophical hermeneutics] [Danish]. Copnehagen: Academica.. p. 521 sider.

25. Stoltz P, Willman A, Bahtsevani C, Spliid Ludvigsen M (2007) Evidensbaseret sygepleje. en bro mellem forskning og klinisk virksomhed [Evidence based nursing - bridging between research and clinical practise] [Danish]. Copenhagen: Gad.

26. Polit DF, Beck CT (2006) Essentials of nursing research. methods, appraisal, and utilization. Philadelphia: Lippincott Williams \& Wilkins.

27. Paquette M, Roy D, Talajic M, Newman D, Couturier A, et al. (2000) Role of gender and personality on quality-of-life impairment in intermittent atrial fibrillation. Am J Cardiol 86: 764-768.

28. Lane DA, Lip GY (2009) Quality of life in older people with atrial fibrillation. J Interv Card Electrophysiol 25: 37-42.

29. Engelmann MD, Pehrson SM (2004) [Quality of life of nonpharmacologically treated patients with atrial fibrillation]. Ugeskr Laeger 166: 2901-2905.

30. Suzuki S, Kasanuki H (2004) The influences of psychosocial aspects and anxiety symptoms on quality of life of patients with arrhythmia: investigation in paroxysmal atrial fibrillation. Int J Behav Med 11: 104-109.

31. Kang Y, Bahler R (2004) Health-related quality of life in patients newly diagnosed with atrial fibrillation. Eur J Cardiovasc Nurs 3: 71-76.

32. Kang Y (2006) Relation of atrial arrhythmia-related symptoms to healthrelated quality of life in patients with newly diagnosed atrial fibrillation: a community hospital-based cohort. Heart Lung 35: 170-177.

33. Reynolds MR, Ellis E, Zimetbaum P (2008) Quality of life in atrial fibrillation: measurement tools and impact of interventions. J Cardiovasc Electrophysiol 19: 762-768.

34. Dorian P, Guerra PG, Kerr CR, O'Donnell SS, Crystal E, et al. (2009) Validation of a new simple scale to measure symptoms in atrial fibrillation: the Canadian Cardiovascular Society Severity in Atrial Fibrillation scale. Circ Arrhythm Electrophysiol 2: 218-224.

35. van den Berg MP, Hassink RJ, Tuinenburg AE, van Sonderen EF, Lefrandt JD, et al. (2001) Quality of life in patients with paroxysmal atrial fibrillation and its predictors: importance of the autonomic nervous system. Eur Heart J 22: 247-253.

36. Lüderitz B, Jung W (2000) Quality of life in patients with atrial fibrillation. Arch Intern Med 160: 1749-1757.

37. Badia X, Arribas F, Ormaetxe JM, Peinado R, de Los Terreros MS (2007) Development of a questionnaire to measure health-related quality of life (HRQoL) in patients with atrial fibrillation (AF-QoL). Health Qual Life Outcomes 5: 37

38. Maryniak A, Walczak F, Bodalski R, Szumowski L, Derejko P, et al. (2006) Atrial fibrillation onset circumstances and their relation to patients' quality of life. Kardiol Pol 64: 1102-1108.
39. Siaplaouras S, Buob A, Heisel A, Böhm M, Jung J (2005) Outpatient electrical cardioversion of atrial fibrillation: efficacy, safety and patients' quality of life. Int J Cardiol 105: 26-30.

40. Härdén M, Nyström B, Kulich K, Carlsson J, Bengtson A, et al. (2009) Validity and reliability of a new, short symptom rating scale in patients with persistent atrial fibrillation. Health Qual Life Outcomes 7: 65 .

41. Ong L, Irvine J, Nolan R, Cribbie R, Harris L, et al. (2006) Gender differences and quality of life in atrial fibrillation: the mediating role of depression. J Psychosom Res 61: 769-774.

42. Ong L, Cribbie R, Harris L, Dorian P, Newman D, et al. (2006) Psychological correlates of quality of life in atrial fibrillation. Qual Life Res 15: 1323-1333.

43. Sears SF, Serber ER, Alvarez LG, Schwartzman DS, Hoyt RH, et al. (2005) Understanding atrial symptom reports: objective versus subjective predictors. Pacing Clin Electrophysiol 28: 801-807.

44. Palm Johansen P, Larsen K, Boehm L, Johansen SL (2012) Patientens oplevelse af at leve med atrieflimren: en oversigtsartikel. [Patients perceptions of living with atrial fibrillation - a review paper] [Danish]. Klin Sygepleje [Clinical Nursing] 26: 15-29.

45. Bohnen M, Shea JB, Michaud GF, John R, Stevenson WG, et al. (2011) Quality of life with atrial fibrillation: do the spouses suffer as much as the patients? Pacing Clin Electrophysiol 34: 804-809.

46. Perret-Guillaume C, Briancon S, Wahl D, Guillemin F, Empereur F (2010) Quality of Life in elderly inpatients with atrial fibrillation as compared with controlled subjects. J Nutr Health Aging 14: 161-166.

47. Spertus J, Dorian P, Bubien R, Lewis S, Godejohn D, et al. (2011) Development and validation of the Atrial Fibrillation Effect on Qualityof-Life (AFEQT) Questionnaire in patients with atrial fibrillation. Circ Arrhythm Electrophysiol 4: 15-25.

48. Pappone C, Vicedomini G, Augello G, Manguso F, Saviano M, et al. (2011) Radiofrequency catheter ablation and antiarrhythmic drug therapy: a prospective, randomized, 4-year follow-up trial: the APAF study. Circ Arrhythm Electrophysiol 4: 808-814.

49. Guédon-Moreau L, Capucci A, Denjoy I, Morgan CC, Périer A, et al (2010) Impact of the control of symptomatic paroxysmal atrial fibrillation on health-related quality of life. Europace 12: 634-642.

50. Mohanty S, Mohanty P, Di Biase L, Bai R, Pump A, et al. (2012) Impact of metabolic syndrome on procedural outcomes in patients with atrial fibrillation undergoing catheter ablation. J Am Coll Cardiol 59: 1295-1301.

51. Peinado R, Arribas F, Ormaetxe JM, Badía X (2010) Variation in quality of life with type of atrial fibrillation. Rev Esp Cardiol 63: 1402-1409.

52. LaMori JC, Mody SH, Gross HJ, DiBonaventura Md, Patel A, et al. (2012) Dyspepsia and disease burden among patients with atrial fibrillation. Crit Pathw Cardiol 11: 14-19.

53. Jaber J, Cirenza C, Jaber J, Amaral A, Almeida de Sousa JM, et al. (2010) Influence of heart rate on quality of life in patients with chronic atrial fibrillation. Clin Cardiol 33: E28-32.

54. Groenveld HF, Crijns HJ, Van den Berg MP, Van Sonderen E, Alings AM, et al. (2011) The effect of rate control on quality of life in patients with permanent atrial fibrillation: data from the RACE II (Rate Control Efficacy in Permanent Atrial Fibrillation II) study. J Am Coll Cardiol 58: 1795-1803.

55. Gehi AK, Sears S, Goli N, Walker TJ, Chung E, et al. (2012) Psychopathology and symptoms of atrial fibrillation: implications for therapy. J Cardiovasc Electrophysiol 23: 473-478.

56. Fichtner S, Deisenhofer I, Kindsmüller S, Dzijan-Horn M, Tzeis S, et al. (2012) Prospective assessment of short- and long-term quality of life after ablation for atrial fibrillation. J Cardiovasc Electrophysiol 23: 121-127.

57. Dąbrowski R, Smolis-Bąk E, Kowalik I, Kazimierska B, Wójcicka M, et al. (2010) Quality of life and depression in patients with different patterns of atrial fibrillation. Kardiol Pol 68: 1133-1139.

58. Cha YM, Wokhlu A, Asirvatham SJ, Shen WK, Friedman PA, et al. (2011) Success of ablation for atrial fibrillation in isolated left ventricular 
diastolic dysfunction: a comparison to systolic dysfunction and normal ventricular function. Circ Electrophysiol 4: 724-732.

59. Ariansen I, Abdelnoor M, Tveit A, Gjesdal K (2010) Guidelines' criteria for rate control in atrial fibrillation: are they useful? Scand Cardiovasc J 44: $132-138$

60. Almeida Gde Q, Noblat Lde A, Passos LC, do Nascimento HF (2011) Quality of life analysis of patients in chronic use of oral anticoagulant: an observational study. Health Qual Life Outcomes 9: 91.

61. Ahmed S, Ranchor AV, Crijns HJ, Van Veldhuisen DJ, Van Gelder IC; CONVERT investigators (2010) Effect of continuous versus episodic amiodarone treatment on quality of life in persistent atrial fibrillation. Europace 12: 785-791.

62. Steg PG, Alam S, Chiang CE, Gamra H, Goethals M, et al. (2012) Symptoms, functional status and quality of life in patients with controlled and uncontrolled atrial fibrillation: data from the RealiseAF crosssectional international registry. Heart 98: 195-201.

63. Rådholm K, Östgren CJ, Alehagen U, Falk M, Wressle E, et al. (2011) Atrial fibrillation (AF) and co-morbidity in elderly. A population based survey of 85 years old subjects. Arch Gerontol Geriatr 52: e170-175.

64. Suleiman M, Koestler C, Lerman A, Lopez-Jimenez F, Herges R, et al. (2012) Atorvastatin for prevention of atrial fibrillation recurrence following pulmonary vein isolation: a double-blind, placebo-controlled, randomized trial. Heart Rhythm 9: 172-178.

65. Dagres N, Nieuwlaat R, Vardas PE, Andresen D, Lévy S, et al. (2007) Gender-related differences in presentation, treatment, and outcome of patients with atrial fibrillation in Europe: a report from the Euro Heart Survey on Atrial Fibrillation. J Am Coll Cardiol 49: 572-577.

66. Funk M, Wood K, Valderrama AL, Dunbar SB (2007) Supraventricular dysrhythmias: nursing research to improve health outcomes. J Cardiovasc Nurs 22: 196-217.

67. Thrall G, Lip GY, Carroll D, Lane D (2007) Depression, anxiety, and quality of life in patients with atrial fibrillation. Chest 132: 1259-1264

68. Valderrama AL, Dunbar SB, Mensah GA (2005) Atrial fibrillation: public health implications. Am J Prev Med 29: 75-80.

69. Pontoppidan J, Nielsen JC, Poulsen SH, Hansen PS (2009) Symptomatic and asymptomatic atrial fibrillation after pulmonary vein ablation and the impact on quality of life. Pacing Clin Electrophysiol 32: 717-726.

70. Kang Y (2009) Gender and culture differences in the quality of life among Americans and Koreans with atrial fibrillation. Nurs Health Sci 11: 301-305.

71. Lane DA, Langman CM, Lip GY, Nouwen A (2009) Illness perceptions, affective response, and health-related quality of life in patients with atrial fibrillation. J Psychosom Res 66: 203-210.

72. Dorian P, Jung W, Newman D, Paquette M, Wood K, et al. (2000) The impairment of health-related quality of life in patients with intermittent atrial fibrillation: implications for the assessment of investigational therapy. J Am Coll Cardiol 36: 1303-1309.

73. McCabe PJ, Schumacher K, Barnason SA (2011) Living with atrial fibrillation: a qualitative study. J Cardiovasc Nurs 26: 336-344.

74. Reynolds MR, Morais E, Zimetbaum P (2010) Impact of hospitalization on health-related quality of life in atrial fibrillation patients in Canada and the United States: results from an observational registry. Am Heart J 160: 752-758.

75. Hegbom F, Sire S, Heldal M, Orning OM, Stavem K, et al. (2006) Shortterm Exercise Training in Patients With Chronic Atrial Fibrillation. J Cardiopulm Rehabil 26: 24-29.

76. Reynolds MR, Walczak J, White S a, Cohen DJ, Wilber DJ (2010) Improvements in symptoms and quality of life in patients with paroxysmal atrial fibrillation treated with radiofrequency catheter ablation versus antiarrhythmic drugs. Circ Cardiovasc Qual Outcomes 3: 615-623.

77. Van Manen M (2007) Researching lived experience?: human science for an action sensitive pedagogy. 2. edition. London Ont.: Althouse Press

78. Eriksson K (2010) Concept determination as part of the development of knowledge in caring science. Scand J Caring Sci 24 Suppl 1: 2-11.

79. Dahlager L, Fredslund H (2008) 7. Hermeneutisk analyse - forståelse og forforståelse [7. Hermeneutic analysis - understanding and preliminary understanding] [Danish]. In: Vallgårda S, Koch L, editors. Forskningsmetoder i Folk. København: Munksgaard Danmark. 154-78.

80. U.S. Food and Drug Administration. Quality of life matters?! Ann Oncol(1995)

81. Zachariae B (2008) Helbredsrelateret livskvalitet [Health related quality of life] [Danish]. Ugeskr læger 170: 819.

82. Maruish ME (Eds) (2011) NEW SF36v2 User Guide, 3rd Edition. Lincoln, RI: QualityMetric Incorporated. p. 325.

83. Delmar C (2010) "Generalizability" as Recognition: Reflections on a Foundational Problem in Qualitative Research. Qual Stud. 1:115-128.

84. Pedersen SS, Kupper N (2010) Representing the patient perspective in the treatment of atrial fibrillation. Europace 12: 305-306.

85. Camm AJ, Kirchhof P, Lip GY, Schotten U, Savelieva I, et al. (2010)Guidelines for the management of atrial fibrillation. The Task Force for the Management of Atrial Fibrillaiton of the European Society of Cardiology (ESC).

86. Eriksen TE, Risør MB (2014) What is called symptom? Med Health Care Philos 17: 89-102.

87. Dijkers M (2007) "What's in a name?" The indiscriminate use of the "Quality of life" label, and the need to bring about clarity in conceptualizations. Int J Nurs Stud 44: 153-155. 